\title{
Analysis and Design of E-Commerce (B2B) with Technology Acceptance Model Method at PT. Global Pharma Indonesia
}

\author{
Ananda Yulianto Putra ${ }^{1}$, Ardie Halim Wijaya ${ }^{2}$, \\ ${ }^{1}$ Buddhi Dharma University, Information System, Banten, Indonesia \\ ${ }^{2}$ Buddhi Dharma University, Management Information System, Banten, Indonesia
}

\begin{tabular}{l}
\hline SUBMISSION TRACK \\
\hline Received : Aug 25, 2020 \\
Final Revision: Sept 19, 2020 \\
Available Online: Sept 29, 2020 \\
KEYWORD \\
\hline B2B, Technology Acceptance Model, E- \\
Commerce, Internet \\
CORRESPONDENCE \\
\hline
\end{tabular}

E-mail: yu4nbu1@gmail.com

\begin{abstract}
Technological advances make competition more competitive so companies are competing in introducing and selling goods by utilizing technology, one of the most rapid technological advances is the internet, the increasing number of internet users has a positive impact on ecommerce. Therefore e-commerce can provide information on goods, facilitate ordering of goods and is not limited by time and distance, to determine the acceptance of technology users, then the Technology Acceptance Model method is used with variables of perceived ease of use, attitude toward using, perceived usefulness, actual usage, behavioral intention. The research sample of 26 employees. Based on the results of the linear analysis noted that attitude toward using can be explained by variations in perceived ease of use, behavioral intention, and perceived usefulness of 52,5 percent, while actual usage can be explained by variations in perceived ease of use, perceived of usefulness, and behavioral intention of 72,2 percent and the remaining 47,5 percent and 27,8 percent are explained by other factors outside the model.
\end{abstract}

\section{INTRODUCTION}

Commerce or trade in general is the work of buying goods from one time and place and selling these goods at other places and times to get profit [1].Technological developments make competition increasingly competitive, so companies are competing to introduce and sell products by taking advantage of technological developments. With the advancement of technology in this era of globalization, every company strives to always increase its marketing and production in order to get the maximum possible profit.

One of the fastest technological advances is the internet. Therefore, with the increasing number of internet users, e-commerce provides various opportunities to conduct electronic commercial transactions. All business people 
easily have a business relationship with another business, and have a direct relationship with consumers.

E-commerce as a form of advancement in information technology has broughta number of changes, including reducing the cost of interaction between buyers and sellers, easier interaction and without limitation of time and place, easier promotion and opportunities to expand market share without having to have large capital, increased transparency and service to consumers [1]. However, based on the results of the 2019 E-commerce Statistics survey by the Central Statistics Agency, only 15.08 percent of businesses use e-commerce. This shows that the business carried out via the internet in Indonesia is still relatively low, business in Indonesia is still dominated by conventional types of business, therefore ecommerce opportunities are wide open [3]. The Technology Acceptance Model method was chosen to explain how technology users accept and use technology related to user work [4].

\section{LITERATURES REVIEW}

From the results of previous research, the results of multiple linear regression analysis obtained a two-sided t test significance level for the variable perceived ease of use of 0.00 , smaller than 0.05 with a positive regression coefficient of 0.428 . This shows that Hypothesis 1 is accepted, which means that perceived ease of use has a positive and significant effect on attitude toward using. This positive effect means that the better the perception of e-commerce users (UKM) about the ease (perceived ease of use) is formed, the more confident the attitude of e-commerce users (UKM) in using e-commerce (attitude toward using) in SMEs. Crafts in Gianyar Regency [4]. And thus the results of other research that Perceived Usefulness has a significant effect on the Utilization of ECommerce in UKM in Palembang City, they believe that using this system can help to get performance benefits in their work. Perceived ease of use has a significant influence on the use of E-Commerce on the benefits of ECommerce which is relatively easy to use and based on the results of short interviews with respondents, information is obtained that most respondents already have expertise or experience using computers. It can be concluded that the variable Perceived Usefulness, Perceived ease of use can determine the benefits and effectiveness of ECommerce in UKM in Palembang City [6].

\section{Website}

Website or shortened as web, can be interpreted as a set of pages consisting of several pages containing information in the form of digital data in the form of text, images, video, audio, and other animations provided through an internet connection [7].

\section{Internet}

Internet (INTERnationalNETwork) can be interpreted as an international computer network, thousands of computer systems that are connected to one another. The presence of the internet has biased national borders so that important information can be quickly and very easily distributed throughout the world. With these connected computers, it is possible to exchange data files and information contained on each computer [8].

\section{E-Commerce}

E-Commerceis the process of buying, selling, transferring, or exchanging products, services or information via computer networks, including the internet [8]. E-Commerce itself has several types of transactions, namely: 
a. Business to business (B2B), transactions carried out by both the seller and the buyer are organizations or companies.

b. Collaborative trading, transactions conducted by collaborative business partners electronically

c. Business to consumer (B2C), transactions are carried out by companies and buyers are individuals

d. Consumer to consumer (C2C), a transaction carried out by someone selling a product or service to another person.

\section{METHODS}

\section{Technology Acceptance Model}

Technology Acceptance Model (TAM) is a model for predicting and explaining how technology users accept and use technology related to user work. The Technology Acceptance Model comes from a psychological theory to explain how information technology user behavior is based on belief, attitude, intention and user behavior relationships. One of the factors that can influence is the user's perception of the usefulness and ease of use of information technology as an action in the context of information technology users so that one's reasons for seeing the benefits and ease of use make that person's actions accept the use of information technology [3].

TAM testing is carried out using research cakeisters so that it can be seen how much the level of understanding and acceptance of system users to the real conditions obtained from users as application users and samples of research conducted [4]. Based on previous empirical studies in this study, the following hypothesis is compiled:

H1: Perceived Ease of Use of E-Commerce positive and significant on Attitude toward Using E-Commerce.
$\mathrm{H} 2$ : Perceived Usefulness of E-Commerce positive and significant on Attitude toward Using E-Commerce.

H3: Behavioral Intention to Use E-Commerce positive and significant on Attitude toward Using E-Commerce.

H4: Perceived Ease of Use of E-Commerce positive and significant on Actual Usage of ECommerce.

H5: Perceived Usefulness of E-Commerce positive and significant on Actual Usage of ECommerce.

H6: Behavioral Intention to Use E-Commerce positive and significant on Actual Usage of ECommerce.

\section{DISCUSSION}

This study took the object of research at PT. Global Pharma Indonesia Tangerang, Banten. This study aims to determine the acceptance of the E-Commerce application system that has been designed. The flow of the order for goods is carried out by the customer, then the order will enter the admin invoice menu, then the admin will confirm the order and the customer makes a payment then uploads proof of payment and the admin will print an invoice and the goods will be sent.

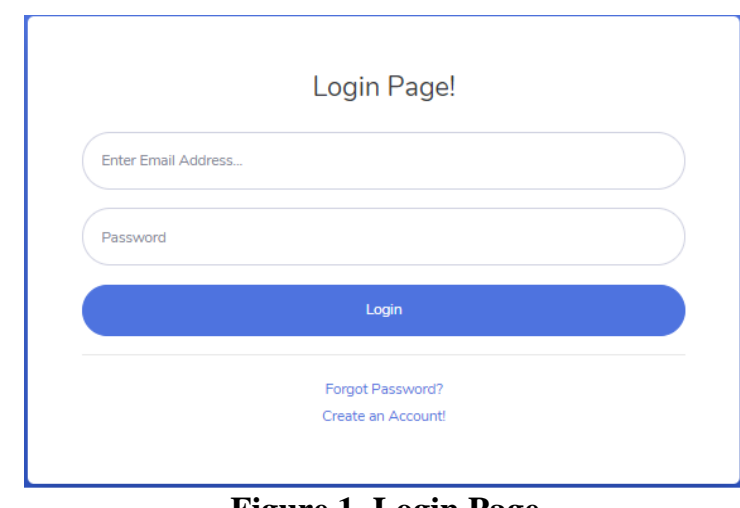

Figure 1. Login Page

The login display of e-commerce applications used in applications that have been designed is shown in Figure 1. 


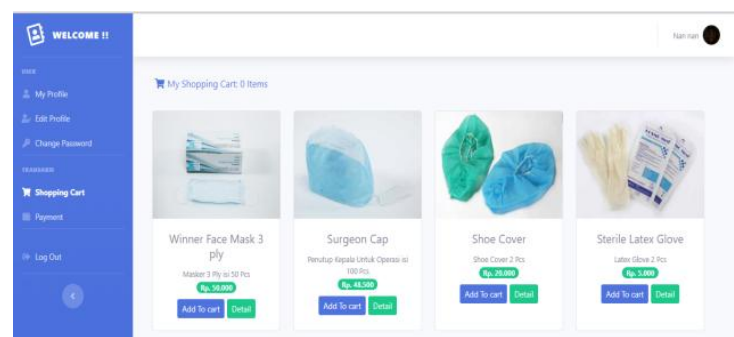

Figure 2. Shopping Cart Display

The display of the ordering page for goods used in e-commerce applications that has been designed is shown in Figure 2.
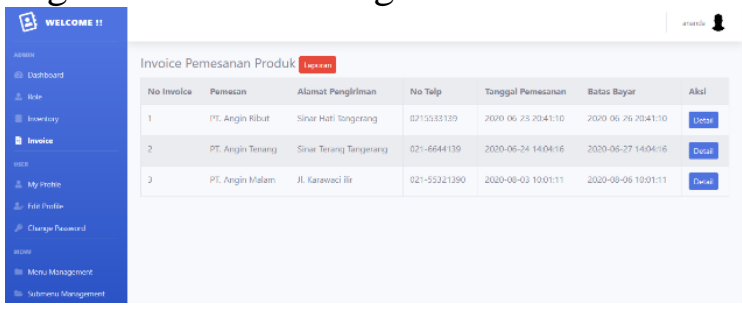

Figure 3.Invoice Menu

Orders that enter will appear on the invoice menu as shown in Figure 3

Based on this application, the research was conducted to determine the effect of each variable. Sampling was conducted at PT. Global Pharma Indonesia on July 6, 2020 for 26 out of a total of 60 employees. The questionnaire was distributed to respondents using the Google Forms application.

Table 1. Detail of Questionnaire

\begin{tabular}{|c|l|c|}
\hline No & Detail of Questionnaire & Total \\
\hline 1 & Distributed Questionnaire & 26 \\
\hline 2 & Returned Questionnaire & 26 \\
\hline 3 & Filled Questionnaire & 26 \\
\hline 4 & $\begin{array}{l}\text { Distributed Questionnaire in } \\
\text { Percentage }\end{array}$ & $100 \%$ \\
\hline 5 & $\begin{array}{l}\text { Returned Questionnaire in } \\
\text { Percentage }\end{array}$ & $100 \%$ \\
\hline
\end{tabular}

The test stage at TAM is testing each statement item, as well as the recap results of the respondents' answers in Table 1.

A description of the answers to the questionnaire in Table 2.

SS : Strongly Agree

$S$ : Agree

$\mathrm{N}$ : Neutral

TS : Disagree
STS: Totally Disagree

Table 2. Recap Answers

\begin{tabular}{|l|l|l|l|l|l|}
\hline Variabel & SS & S & N & TS & STS \\
\hline PEoU1 & 11,53 & 73,07 & 15,38 & & \\
\hline PEoU2 & 3,84 & 80,76 & 15,38 & & \\
\hline ATU1 & 15,38 & 80,76 & 3,84 & & \\
\hline ATU2 & 11,53 & 84,61 & 3,84 & & \\
\hline PU1 & 7,69 & 80,76 & 11,53 & & \\
\hline PU2 & 11,53 & 80,76 & 7,69 & & \\
\hline PU3 & 19,23 & 80,76 & & & \\
\hline BI1 & 7,69 & 88,46 & 3,84 & & \\
\hline BI2 & 11,53 & 84,61 & 7,69 & & \\
\hline AU & & 88,46 & 11,53 & & \\
\hline Total & 99,95 & 823,1 & 80,72 & & \\
\hline Prosentase & $\mathbf{9 , 9 6}$ & $\mathbf{8 2 , 0 5}$ & $\mathbf{8 , 0 4}$ & & \\
\hline
\end{tabular}

Source : Result of the questionnaire data

Table 3. Summary of Answers

\begin{tabular}{|l|l|}
\hline x1 & Perceived Ease of Use / PEoU 1 \\
\cline { 2 - 2 } & Perceived Ease of Use / PEoU 2 \\
\hline x2 & Perceived Usefulness / PU 1 \\
\cline { 2 - 2 } & Perceived Usefulness / PU 2 \\
\cline { 2 - 2 } & Perceived Usefulness / PU 3 \\
\hline x3 & Behavioral Intention / BI 1 \\
\cline { 2 - 2 } & Behavioral Intention / BI 2 \\
\hline y1 & Attitude Toward Using / ATU 1 \\
\cline { 2 - 2 } & Attitude Toward Using / ATU 2 \\
\hline y2 & Actual Usage /AU \\
\hline
\end{tabular}

From the table variables above, the Instrument Test, Classical Assumption Test and Multiple Linear Analysis were carried out.

1) Instrument Test

a. Validity Test

Table 4. Validity Test Of Variabel X

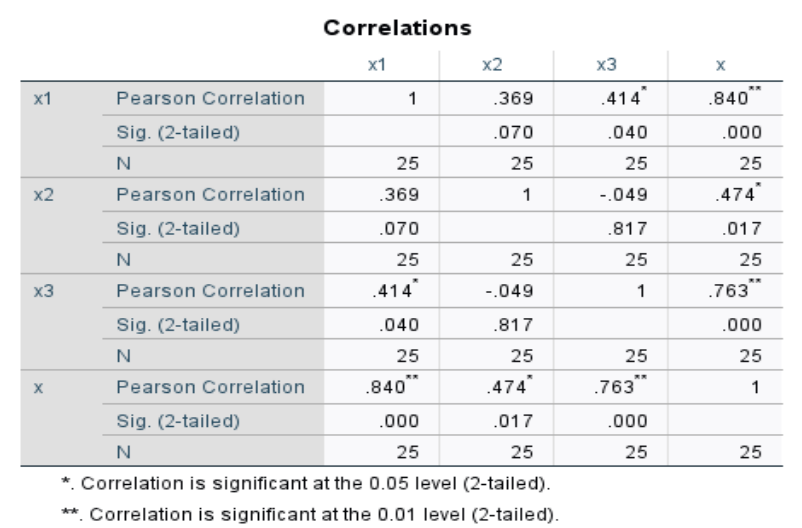

Source :Output SPSS 
Tabel 5. Validity Test Of Variabel Y

Correlations

\begin{tabular}{|c|c|c|c|c|}
\hline & & y1 & y2 & $y$ \\
\hline \multirow[t]{3}{*}{$\mathrm{y1}$} & Pearson Correlation & 1 & $.463^{*}$ & $.816^{\mathrm{kx}}$ \\
\hline & Sig. (2-tailed) & & .020 & .000 \\
\hline & $\mathrm{N}$ & 25 & 25 & 25 \\
\hline \multirow[t]{3}{*}{ y2 } & Pearson Correlation & $.463^{x}$ & 1 & $.890^{* x}$ \\
\hline & Sig. (2-tailed) & .020 & & .000 \\
\hline & $\mathrm{N}$ & 25 & 25 & 25 \\
\hline \multirow[t]{3}{*}{ y } & Pearson Correlation & $.816^{\mathrm{x}}$ & $.890^{\star \pi}$ & 1 \\
\hline & Sig. (2-tailed) & .000 & .000 & \\
\hline & $\mathrm{N}$ & 25 & 25 & 25 \\
\hline
\end{tabular}

Source: OutputSPSS

The results of the observations on the $r$ table obtained the value of the sample $(\mathrm{N})=$ 26 of 0.3882 . consisting of $y 1, y 2$ all of which produce values ( $r$ count) $>$ than $r$ table, and it can be concluded that all instruments in this study are declared valid.

b. Reliability Test

Table 6. Reliability Test OfVariabel X

\section{Reliability Statistics}

\begin{tabular}{r|r}
$\begin{array}{c}\text { Cronbach's } \\
\text { Alpha }\end{array}$ & N of Items \\
\hline .816 & 7 \\
\hline
\end{tabular}

Source: Output SPSS

Table 7.Reliability Test OfVariabel Y

\section{Reliability Statistics}

\begin{tabular}{r|r}
$\begin{array}{c}\text { Cronbach's } \\
\text { Alpha }\end{array}$ & N of Items \\
\hline .824 & 3 \\
\hline
\end{tabular}

Source: OutputSPSS

From the results of the reliability testing above, which was carried out using the SPSS for windows application, it was stated that the $\mathrm{x}$ and $\mathrm{y}$ variables were declared reliable, because both cronbach's alpha values were $>0.60$ and could be continued to the next test.

2) Classic Assumption Test

a. Normalitiy Test
Table 8.Normalitiy Test

One-Sample Kolmogorov-Smirnov Test

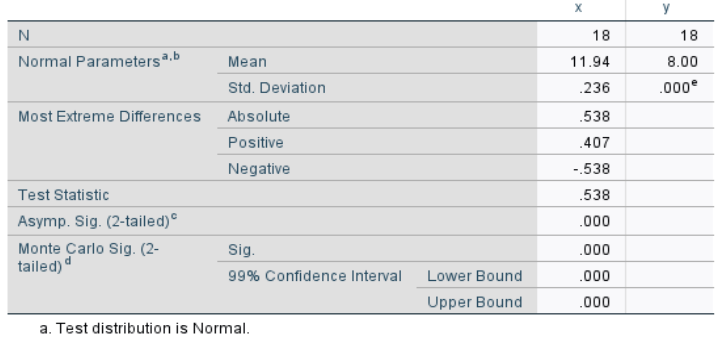

Source: Output SPSS

The normality test was done by using the Kolmogorov Smirnov test. The results of the normality test showed that the data were not normally distributed because the results of normality testing using SPSS for windows showed Asymp. Sig. (2-tailed) $<0.05$ because of the Asymp. Sig. (2tailed) is worth 0.000 .

b. Multicollinearity Test

Table 9.Multicollinearity Test

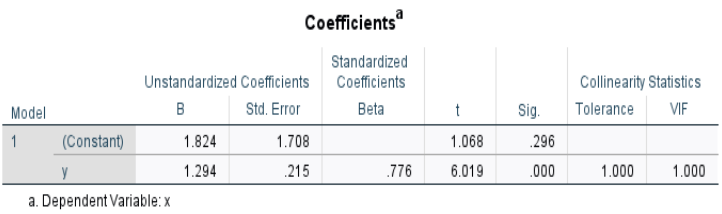

Source: Output SPSS

From the calculation results in the table above, it shows that the tolerance value is greater than 0.1 and the VIF value $=1$, where the value is less than 10 , so it can be concluded that it is free from multicollinearity.

c. Heteroscedasticity Test

Table 10.Heteroscedasticity Test

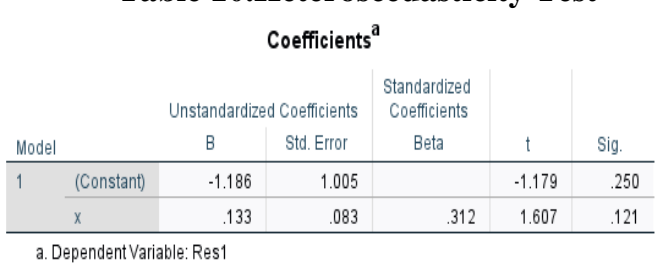

Source: Output SPSS 
From the results of heteroscedasticity testing using the Glejser test, the significance results of the $\mathrm{x}$ variable or the independent variable showed a result of 0.121 , which is above the standard significance value of 0.05 . So it can be concluded that heteroscedasticity does not occur.

3) Multiple Linear Analysis

a. F Test

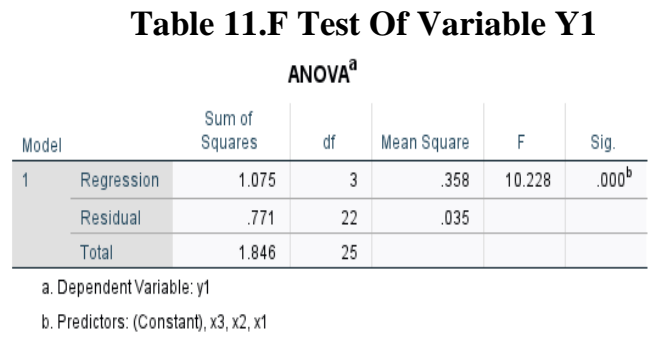

Source: Output SPSS

Table 12.F Test Of Variable Y2

ANOVA $^{\mathrm{a}}$

\begin{tabular}{|c|c|c|c|c|c|c|}
\hline Mode & & $\begin{array}{l}\text { Sum of } \\
\text { Squares }\end{array}$ & df & Mean Square & $\mathrm{F}$ & Sig. \\
\hline \multirow[t]{3}{*}{1} & Regression & 3.021 & 3 & 1.007 & 22.635 & $.000^{\mathrm{b}}$ \\
\hline & Residual & .979 & 22 & .044 & & \\
\hline & Total & 4.000 & 25 & & & \\
\hline
\end{tabular}

Source: Output SPSS

The results of the $F$ test show that the value of $F$ count $>F$ table is 3.37 for the first dependent variable (attitude toward using) (Y1) of 10.228 with a significant $F$ or $\mathrm{P}$ value of 0.000 less than $\alpha=0.05$ and the calculated $\mathrm{F}$ value> $\mathrm{F}$ table 3.37 for the second dependent variable (actual usage) of 22.635 with a significant $\mathrm{F}$ or $\mathrm{P}$ value of 0.000 less than $\alpha=0.05$, this means that the model used is feasible and is able to predict or explain the phenomenon under study. b. T Test

Tabel 13.T Test Of Variable Y1

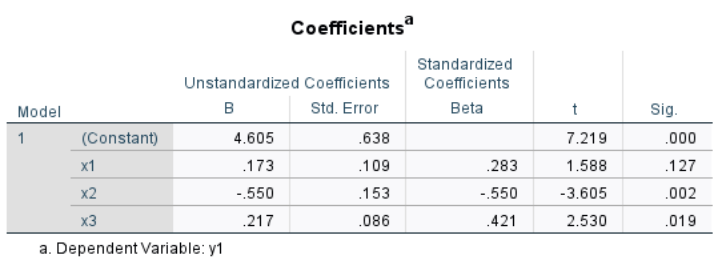

Source: Output SPSS

Tabel 14. T Test Of Variable Y2

Coefficients $^{\mathrm{a}}$

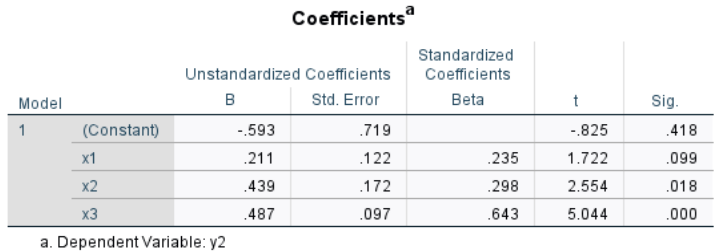

Source: OutputSPSS

By comparing the value of $\mathrm{T}$ count $>\mathrm{T}$ table, then $\mathrm{HO}$ is rejected and $\mathrm{Ha}$ is accepted, then if $\mathrm{T}$ count $<\mathrm{T}$ table, then $\mathrm{HO}$ is accepted and Ha is rejected. Based on the results of the $T$ test on the first dependent variable (attitude toward using) (Y1) only Behavioral Intention (X3) is H0 rejected and $\mathrm{Ha}$ is accepted and has a significant effect with the value of $\mathrm{T}$ count $>\mathrm{T}$ table, namely $2.530>2.056$ with a significant 0.019 less than $\alpha=0,05$ while the $\mathrm{T}$ test results on the variable for the second dependent variable (actual usage) (Y2) variable Perceived Usefulness (X2) and Behavioral Intention (X3) H0 is rejected and $\mathrm{Ha}$ is accepted and has a significant effect with the value of $\mathrm{T}$ count $>\mathrm{T}$ table namely $2.554>2.056$ with a significant 0.018 less than $\alpha=0.05$ in the Perceived Usefulness (X2) variable and 5.044> 2.056 with a significant 0.000 less than $\alpha=0.05$ in the Behavioral Intention (X3) variable. 
c. Coefficient of Determination Test

Table 15. Coefficient of Determination Test Variable Y1

\begin{tabular}{|c|c|c|c|c|}
\hline \multicolumn{5}{|c|}{ Model Summary } \\
\hline Model & $\mathrm{R}$ & R Square & $\begin{array}{l}\text { Adjusted R } \\
\text { Square }\end{array}$ & $\begin{array}{l}\text { Std. Error of } \\
\text { the Estimate }\end{array}$ \\
\hline 1 & $.763^{\mathrm{a}}$ & .582 & .525 & .187 \\
\hline
\end{tabular}

Source: Output SPSS

Table 16. Coefficient of Determination Test Variable Y2

\begin{tabular}{|c|c|c|c|c|}
\hline \multicolumn{5}{|c|}{ Model Summary } \\
\hline Model & $\mathrm{R}$ & R Square & $\begin{array}{l}\text { Adjusted R } \\
\text { Square }\end{array}$ & $\begin{array}{l}\text { Std. Error of } \\
\text { the Estimate }\end{array}$ \\
\hline 1 & $.869^{\mathrm{a}}$ & .755 & .722 & .211 \\
\hline
\end{tabular}

Source: Output SPSS

The amount of Adjusted R2 for the first dependent variable (attitude toward using) is 0.525 . This means that variations in attitude toward using can be explained by variations in perceived ease of use, behavioral intention, and perceived usefulness of 52.5 percent, while the remaining 47.5 percent is explained by other factors outside the model. In the second dependent variable (actual usage), the amount of Adjusted R2 is 0.722. This means that actual usage variations can be explained by variations in perceived ease of use, perceived usefulness, and behavioral intention by 72.2 percent, while the remaining 27.8 percent is explained by other factors outside the model.

\section{CONCLUSION}

Based on the research that has been done, it can be concluded that Perceived ease of use, Perceived Usefulness, and Behavioral intention have a significant effect on Actual Usage and can be explained by variations in perceived ease of use, perceived of usefulness, and behavioral intention by 72.2 percent, while the rest 27.8 percent is explained by other factors outside the model.

\section{REFERENCES}

[1] A. M. R. Laode, Sutardi and J. N. , "Pembuatan Web E-Commerce Pada Toko Kenime Store Menggunakan Sistem Rekomendasi Berbasis Metode Collaborative Filtering Dengan Algoritma Adjusted Cosine Similarity," semanTIK, Volume 3 No. 2, pp. 227-235, 2017.

[2] S. Kosasi, "Perancangan Dan Pemanfaatan E-Commerce Untuk Memperluas Pasar Produk Furniture," Seminar Nasional Teknologi Informasi dan Komunikasi 2015 (SENTIKA 2015), pp. 17-24, 2015.

[3] BPS, 06 Juni $2020 . \quad$ AOnline]. Available: https://www.bps.go.id/publication/2019/12/18/fd1e96b05342e479a83917c6/statistik-ecommerce-2019.html.

[4] E. R. N. A. P. Tri Irawati, "Penggunaan Metode Technology Acceptance Model (TAM) Dalam Analisis Sistem Informasi Alista (Application Of Logistic And Supply Telkom 
Akses)," Accounting Information Systems and Information Technology Business Enterprise, Volume 04 Nomor 02, pp. 106-120, 2019.

[5] I. P. Y. I Wayan Santika, "Analisis Technology Acceptance Model Terhadap Penggunaan ECommerce Pada Ukm Kerajinan Di Gianyar," Prosiding Seminar Nasional AIMI, pp. 255264, 2017.

[6] Yulistia, "Analisis Pengaruh Efektivitas dan Manfaat E-Commerce Terhadap Sikap Dan Perilaku Pengguna Dengan Menggunakan Metode TAM (Studi Kasus: UKM Kota Palembang)," Jatisi, Vol. 4 No.1, pp. 93 - 100, 2017.

[7] S. H. A. Andi Christian, "Rancang Bangun Website Sekolah Dengan Menggunakan Framework Bootstrap (Studi Kasus SMP Negeri 6 Prabumulih)," SISFOKOM, Volume 07 Nomor 01, pp. 22 - 27, 2018.

[8] Yakub, Pengantar Sistem Informasi, Yogyakarta: Graha Ilmu, 2012.

\section{BIOGRAPHY}

Ananda Yulianto Putra was born in Tangerang, on 20 October 1996. He was a student of the University of Buddhi Dharma, majored in Information System.

Ardie Halim Wijaya was born in Tangerang, on 28 August 1991. He obtained his bachelor of computer (S.Kom) at STMIK Buddhi in 2013 and completed his master of computer graduate program (M.Kom) at University of Budi Luhur in 2016. He was the lecturer and head of Informatics Management study program at University of Buddhi Dharma. 